Dept. of Food Hygiene,

Fac. Vet. Med., Alexandria University, Egypt.

\title{
PSCHROTROPHS; ECONOMIC IMPORTANCE, PUBLIC HEALTH HAZARDS AND ITS CONTROL IN RAW MILK
}

(With 2 Tables and 4 Figures)

By

\section{A.A. AMER; A.S. AIAD* and NABILA F. SOLIMAN*}

* Dept. of Food Hygiene, Animal Health Research Institute, Alexandria.

(Received at 20/9/2008)

\section{الميكروبات المحبة للبرودة، الأهمية الاقتصادية، الخطورة الصحية والتحكم بها في اللبن الخام}

عدرو عبل المؤمن عامر ، أحمد صلاح اللين عياد ، نبيلة السبي سليمان

تعتبر الألبان ومنتجاتها من أكثر الأغذية تعرضاً للتلوث بالمبكروبات المختلفة التى التى

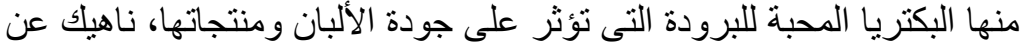

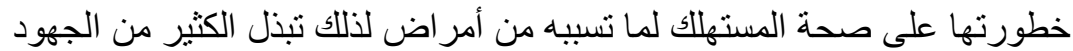

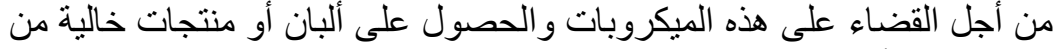

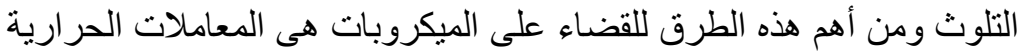

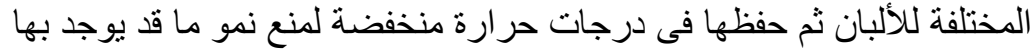

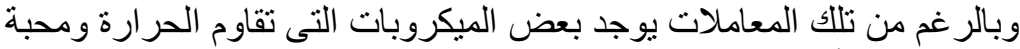

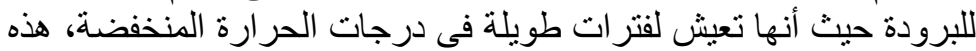

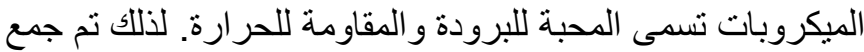

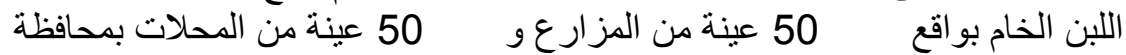

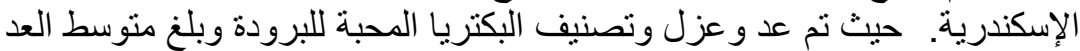

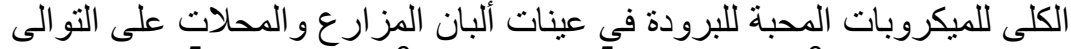
هو

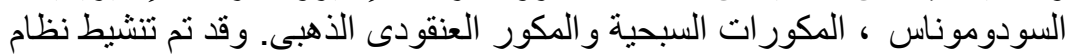

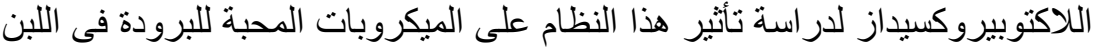

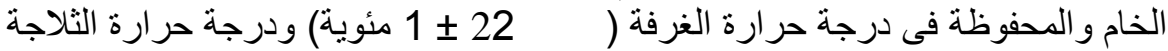

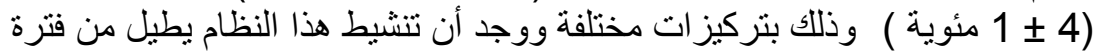

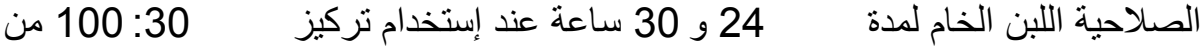

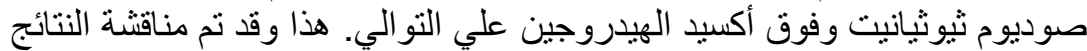
من الناحيتين الإقتصادية و الصحية و إقتر اح الإجر اءعات الصيد الصحية الواجب إنباعها 


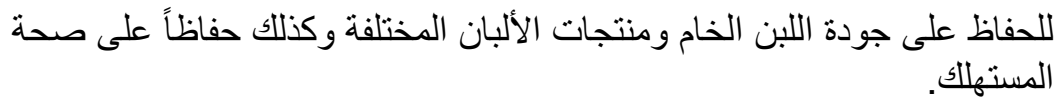

\section{SUMMARY}

Psychrotrophs in milk and milk products are not surprising because these organisms are widely distributed in nature and common contaminants of dairy products. Storage of milk and such products for long period at refrigerated temperature has resulted in quality problems by the action of lipase and protease enzymes produced during their growth which is heat stable causing spoilage. The objective of study is to investigate the incidence of psychrotrophs in raw milk and spot light on their economic and public health importance as well as to study the effect of activation of lactoperoxidase system on the shelf-life of raw milk kept at room temperature $\left(22 \pm 1{ }^{\circ} \mathrm{C}\right)$ and refrigerator temperature $\left(4 \pm 1{ }^{\circ} \mathrm{C}\right)$. Material, One hundred random samples of raw milk were collected in clean, dry and sterile sampling bottles (500 $\mathrm{ml}$ each) from dairy farms and shops (50 each) at different sites of the local markets in Alexandria Governorate. Result, All samples were contaminated with psychrotrophs with mean count of $1.50 \times 10^{6} \pm 3.3 \times 10^{5}$ and $3.20 \times 10^{6} \pm 4.5 \times 10^{5}$ $\mathrm{cfu} / \mathrm{ml}$ in examined farm and market milk samples, respectively. The shelf life of raw milk with activation of lactoperoxidase system with Sodium thiocyanate $(\mathrm{NaSCN})$ and Hydrogen peroxide $\left(\mathrm{H}_{2} \mathrm{O}_{2}\right)$ at concentrations of $(10: 25,14: 30$, and $30: 100 \mathrm{ppm})$ has prolonged to 16 , 16 , and 24 hours when kept at room temperature and to 20,20, and 30 hours when kept at refrigerator temperature, respectively. Conclusion, Strict hygienic measures should be highly recommended during production of raw milk, processing; transportation and storage of pasteurized milk to ensure a high quality product and to safeguard consumers from public health hazards.

Key words: Psychrotrophs, raw milk, lactoperoxidase system

\section{INTRODUCTION}

Extended refrigerated storage of milk on the farm, in transport, at dairy plant, and in the supermarket have required an increased shelf-life of fluid milk. Storage of milk for long periods at refrigeration temperatures has resulted in new quality problems for the dairy industry. These problems are related to growth and metabolic activities of 
psychrotrophs which are common contaminants of milk (Bramley and Mckinnon, 1990 and Kirin, 2001). As psychrotrophs increase in number throughout refrigerated storage, enzymes are synthesized during microbial growth in milk. Many of these enzymes are heat-stable, and biochemically alter the milk eventually causing spoilage (Prieto et al., 2002). Moreover, there are emerging pathogens which can grow during refrigeration storage and cause diseases to the consumer (McClements et al., 2001 and Teo et al., 2001).

Psychrotrophs that have both thermoduric and psychrophilic properties play an important role in milk spoilage. Most of these organisms have lipolytic, caseinolytic or sacchorolytic activities during storage of pasteurized milk in the holding tanks. The growth of psychrotrophs in milk is responsible for sweet curdling in fluid milk, bitty cream, bitter, fruity, rancid, sour, yeasty, putrid and unclean off flavor (Bodyfelt 1980 and Meer et al., 1991). Psychrotrophs strains produce extracellular heat-resistant lipase as well as proteinases during storage of milk leading to destruction and degradation of the micellar structure of milk protein and fat globules (Jay, 1997). Moreover, almost $40 \%$ of the psychrotrophic isolates could degrade both fat and protein, while $80 \%$ of the isolates exhibited phospholipase activity, which can destroy the native milk fat globule membrane, resulting in destabilization of the fat emulsion in milk. As a result, churning of the fat occurs and the phenomenon is known as bitty cream (Muir, 1996).

The lactoperoxidase thiocyanate-hydrogen peroxide system (LPS) is one of the better known natural antimicrobial systems of milk. The lactoperoxidase system has been proposed as a mean for control of the indigenous psychrotrophic flora in milk (Zajac et al., 1983 and IDF, 1985) as well as against pathogenic bacteria as B. cereus, Listeria monocytogenes and Staphylococcus aureus (El-Shenawy et al., 1990 and Arques et al., 2008). LPS activation enhanced the shelf life of milk and typically increased keeping quality from 10 to around 20 hours, but it was clear that the effectiveness of LPS depends on the type and concentrations of the activators of the system (Fweja et al., 2007). The LP-system has very strong bactericidal and bacteriostatic properties and may be acceptable for preservation of raw milk under difficult conditions such as lack of cooling facilities, high ambient temperatures and distant transport. It is also important to note that the complete LPS occurs naturally in man and animals biological fluids, where it functions as an indigenous antibacterial system promoting a balanced flora in the oral cavity and intestinal tract (IDF, 1988 and Metwally and Nasr, 1992). 
The LP-system consists of 3 components, lactoperoxidase (Lpo), thiocyanate anion $(\mathrm{SCN})$ and hydrogen peroxide $\left(\mathrm{H}_{2} \mathrm{O}_{2}\right)$. The LPsystem is very active, both in vivo and in vitro, at low concentration and, just as other natural defense factors, without undesirable side-effects. In addition to its anti-microbial activity, LP-system may also perform other biological functions such as degradation of various carcinogens, inactivation of viruses and protection of human cells against (per) oxidative effects. Synergistic effects of LP-system in combination with other naturally occurring defense systems such as lactoferrin and lysozyme may be expected. (Dewit and Van Hooydonk, 1996).

Hence, this study planned to determine the incidence, economic and public health importance of psychrotrophs in raw milk and effect of activation of lactoperoxidase system on the shelf-life of raw milk kept at room temperature $\left(22 \pm 1{ }^{\circ} \mathrm{C}\right)$ and refrigerator temperature $\left(4 \pm 1{ }^{\circ} \mathrm{C}\right)$

\section{MATERIALS and METHODS}

\section{Collection of samples}

One hundred random samples of raw milk were collected in clean, dry and sterile sampling bottles $(500 \mathrm{ml}$ each) from dairy farms and shops (50 each) at different sites of the local markets in Alexandria Governorate. The collected samples were transferred to the laboratory in ice box with a minimum of delay where they were immediately examined. Each sample was thoroughly mixed and subjected to peroxidase test (Storch's test) (Lampert, 1975) to exclude samples proved to be heat-treated.

2. Preparation of ten-fold serial dilution (APHA, 1992):

3. Total psychrotrophic count of raw milk samples (IDF, 1985).

4. Isolation and identification of psychrotrophic bacteria (Bailey and Scott, 1998)

5. Effect of activation of lactoperoxidase system on the shelf-life of raw milk kept at room temperature $\left(22 \pm 1^{\circ} \mathrm{C}\right)$ and refrigerator temperature $\left(4 \pm 1{ }^{\circ} \mathrm{C}\right)$ :

Eight liters of raw milk samples were collected from the dairy farm of Faculty of Veterinary Medicine, Alexandria University. Raw milk was divided into 8 groups. The groups were treated with Sodium thiocyanate $(\mathrm{NaSCN})$ and Hydrogen peroxide $\left(\mathrm{H}_{2} \mathrm{O}_{2}\right)(0.00: 0.00,10: 25$, 14:30, and 30:100 ppm). Each treated milk was subdivided into 2 subgroups. The first one was stored at room temperature $\left(22 \pm 1{ }^{\circ} \mathrm{C}\right)$ and the other was stored at refrigerator temperature $\left(4 \pm 1^{\circ} \mathrm{C}\right)$. All treated 
milks were subjected for enumeration of psychrotrophs at zero time and every four hours until milk clots on boiling as well as $\mathrm{pH}$ measurement.

\section{RESULTS}

The obtained results were recorded in Tables 1-2 and Figures 1-4

Table 1: Psychrotrophic bacterial count of examined farm and market milk (100 samples).

\begin{tabular}{|c|c|c|c|}
\hline \multirow{2}{*}{ Source of milk } & \multicolumn{2}{|c|}{ Positive samples } & Psychrotrophic count cfu/ml \\
\cline { 2 - 4 } & No. & $\%$ & Mean \pm SEM \\
\hline Farm milk & 50 & 100 & $1.50 \times 10^{6} \pm 3.3 \times 10^{5}$ \\
\hline Market milk & 50 & 100 & $3.20 \times 10^{6} \pm 4.5 \times 10^{5}$ \\
\hline
\end{tabular}

Table 2: Incidence of psychrotrophic bacteria isolated from farm and market milk (100 samples).

\begin{tabular}{|l|c|c|c|c|}
\hline \multirow{2}{*}{ Isolated organism } & \multicolumn{2}{|c|}{ Farm Milk } & \multicolumn{2}{c|}{ Market Milk } \\
\cline { 2 - 5 } & No. & $\%$ & No. & $\%$ \\
\hline Bacillus cereus & 12 & 24 & 8 & 16 \\
Bacillus megaterium & 0 & 0 & 5 & 10 \\
Citrobacter freundii & 3 & 6 & 2 & 4 \\
Enterobacter aerogenes & 2 & 4 & 1 & 2 \\
Enterobacter cloacae & 3 & 6 & 1 & 2 \\
Escherichia coli & 4 & 8 & 2 & 4 \\
Klebsiella pneumoniae & 1 & 2 & 3 & 6 \\
Pseudomonas fluorescens & 4 & 8 & 3 & 6 \\
Pseudomonas aeruginosa & 3 & 6 & 3 & 6 \\
Provedencia spp. & 1 & 2 & 1 & 2 \\
Staphylococcus aureus & 3 & 6 & 3 & 6 \\
Streptococcus faecalis & 5 & 10 & 5 & 10 \\
\hline
\end{tabular}



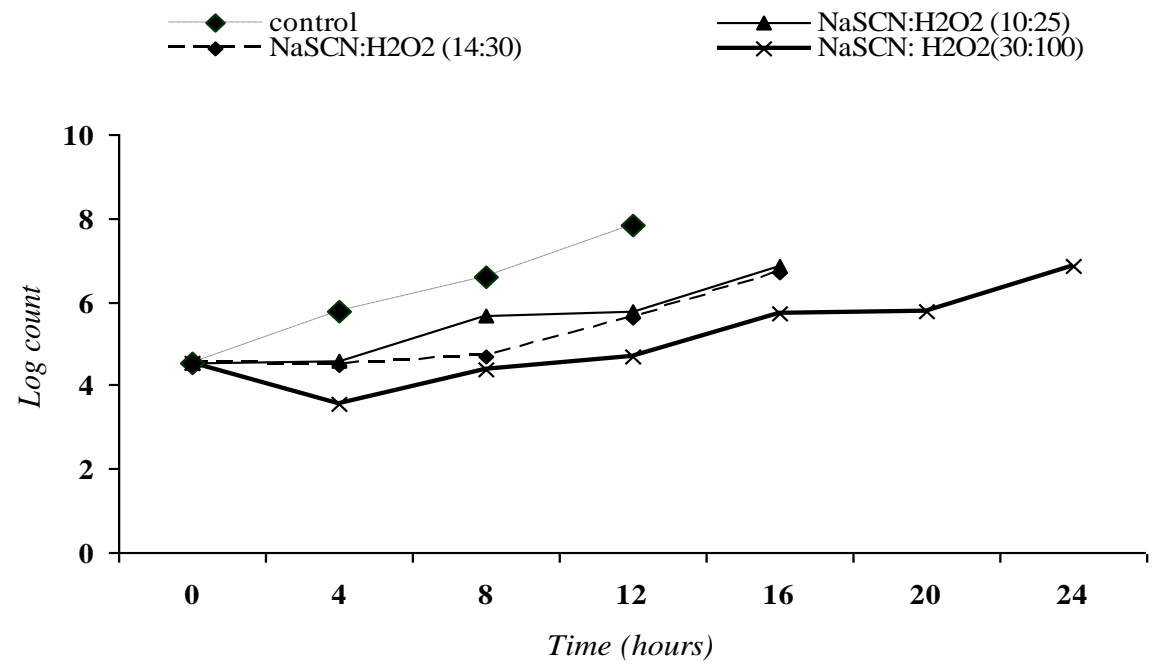

Fig. 1: Effect of Lactoperoxidase system activated by $\mathrm{NaSCN}: \mathrm{H}_{2} \mathrm{O}_{2}$ at different concentrations on psychrotrophic bacterial count in raw milk kept at room temperature.
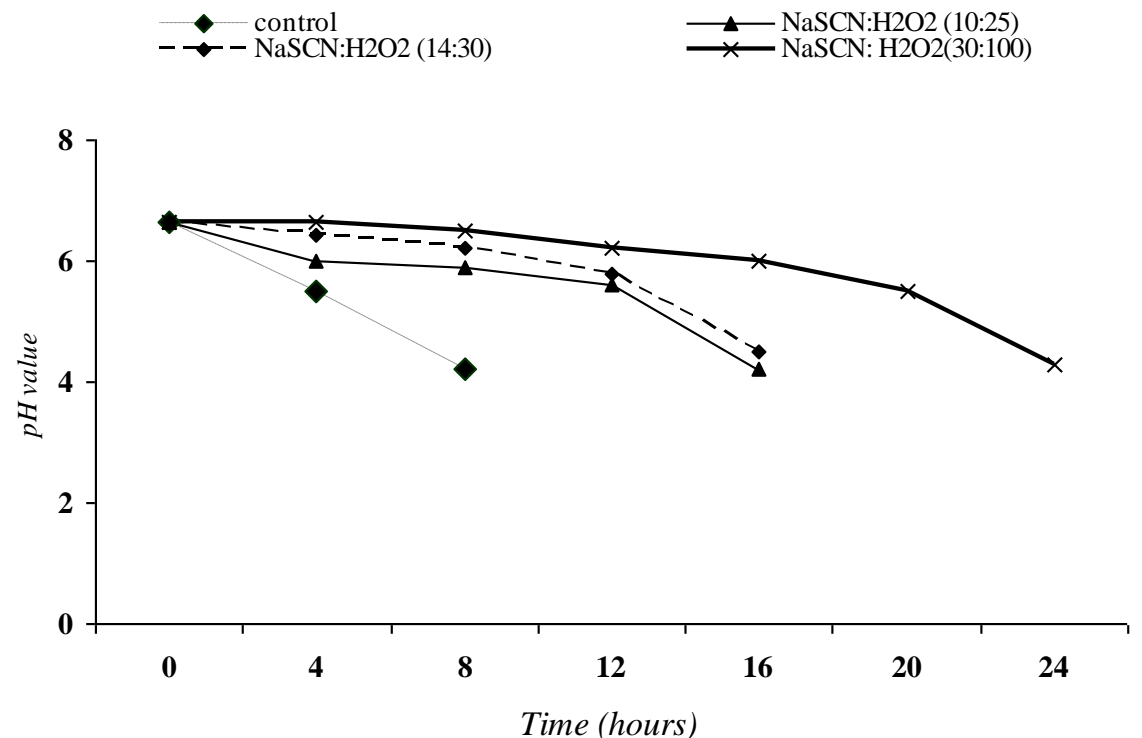

Fig. 2: Effect of Lactoperoxidase system activated by $\mathrm{NaSCN}: \mathrm{H}_{2} \mathrm{O}_{2}$ at different concentrations on $\mathrm{pH}$ value of raw milk kept at room temperature. 
$\longrightarrow$ control

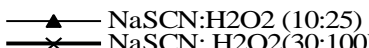

NaSCN: $\mathrm{H} 2 \mathrm{O} 2(30: 100)$

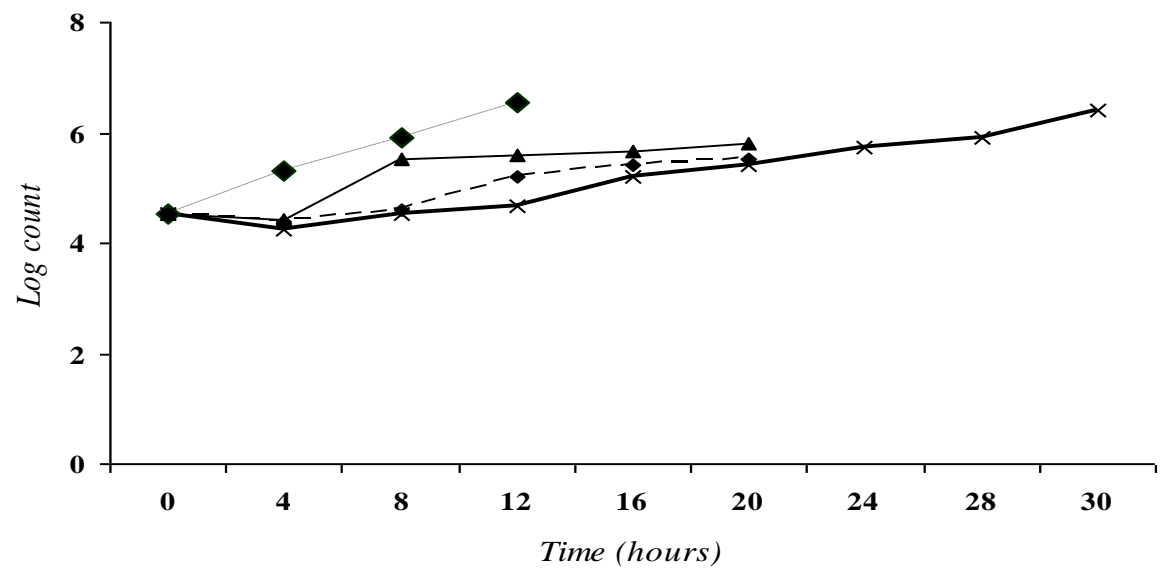

Fig. 3: Effect of Lactoperoxidase system activated by $\mathrm{NaSCN}: \mathrm{H}_{2} \mathrm{O}_{2}$ at different concentration on psychrotrophic bacterial count in raw milk kept at refrigerator temperature.
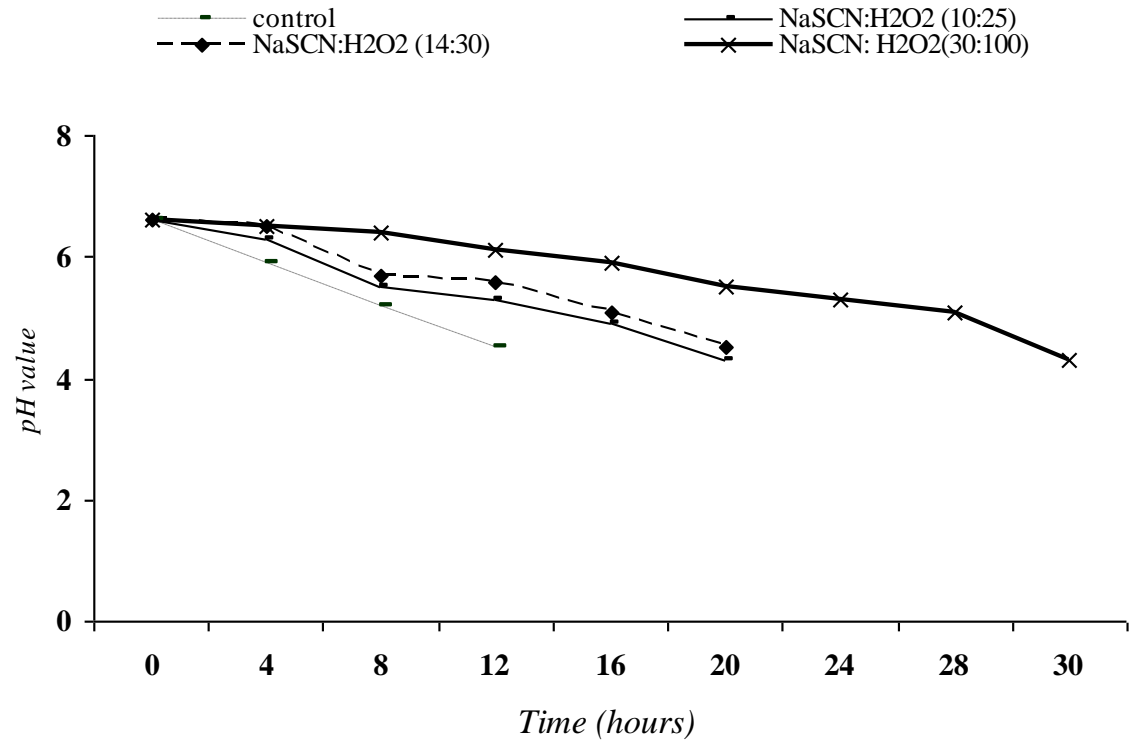

Fig. 4: Effect of Lactoperoxidase system activated by $\mathrm{NaSCN}: \mathrm{H}_{2} \mathrm{O}_{2}$ at different concentrations on $\mathrm{pH}$ value of raw milk kept at refrigerator temperature. 


\section{DISCUSSION}

\section{(a) Psychrotrophic bacterial count:}

All samples were contaminated with psychrotrophs with mean counts of $1.50 \times 10^{6} \pm 3.3 \times 10^{5}$ and $3.20 \times 10^{6} \pm 4.5 \times 10^{5} \mathrm{cfu} / \mathrm{ml}$ in examined farm and market milk samples, respectively (Table, 1). During cold storage after milk collection, psychrotrophic bacterial populations dominate the microflora, and their extracellular enzymes, mainly proteases and lipases, contribute to the spoilage of dairy products. Milk production methods, equipment and on farm storage have changed generally for the better during the last decades. However, the microbiological quality of raw milk supplies, produced under apparently good hygienic conditions and stored under refrigeration, still causes concern because of the possible adverse effects of prolonged refrigerated storage of raw milk. This storage gives a chance to psychrotrophs to multiply.

Psychrotrophs are rarely present in the udder; the numbers of psychrotrophs in raw milk depend on sanitary condition during production and on duration and temperature of storage before the milk is processed. They are widely distributed in nature and were isolated from soil, mud, air, feces and water (Kirin, 2001). Moreover, poorly cleaned and sanitized dairy farm and processing dairy equipment constitute major sources of contamination of raw milk. While, Muir (1996) reported that spoilage of raw milk as evidenced by lipolysis or proteolysis does not occur until counts in excess of $5 \times 10^{6} / \mathrm{ml}$.

Psychrotrophic bacteria from numerous genera have been isolated from raw milk, both gram negative (Citrobacter, Enterobacter, Escherichia and Pseudomonas) and gram positive (Bacillus, Streptococcus, and Staphylococcus) (Table, 2).

\section{(b) Economic importance of the isolated organisms:}

Growth of psychrotrophic bacteria is primarily responsible for limiting the keeping quality of milk and dairy products held at temperatures below $7{ }^{\circ} \mathrm{C}$. Slight biochemical changes occur in the early growth phase of psychrotrophs, resulting in a lack of freshness or a stale taste. Upon subsequent cold storage a variety of defects become apparent. Development of these off flavours is usually a result of proteolysis and/or lipolysis by psychrotrophs. The two degenerative reactions of psychrotrophs in milk are of great concern to dairy manufacture and processors. 
The majority of Pseudomonas bacteria produce extracellular enzymes, which are extremely thermostable. The most important of these enzymes from the commercial viewpoint are the proteases and lipases, both of which are able to withstand HTST (high temperatureshort time) and UHT (ultra-heat treatment) treatment (Cogan, 1977). Even at very low concentrations, these enzymes are capable of breaking down the casein and fat in milk and milk products, which are subjected to long-term storage (Law, 1979). Degradation of milk components through various enzymatic activities can reduce the shelf-life of processed milk. For example, digestion of casein by proteases can lead to bitter flavour, clotting and gelation of milk. Lipases hydrolyze tributyrin and milk fat to yield free fatty acids, which cause milk to taste rancid, bitter, unclean and soapy (Cousin, 1982). Moreover, the hydrolytic products of milk fats and proteins decrease the organoleptic quality of fluid milk products.

\section{(c) Public health importance of psychrotrophs isolated from raw milk:}

Bacillus cereus is a food poisoning microorganism widely distributed in nature and frequently contaminates milk and dairy products. Bacillus cereus is the causative agent of two distinct forms of gastroenteritis disease connected to food poisoning. The diarrhoeal syndrome which is characterized by abdominal pain and diarrhea, with an incubation period of 8 to 16 hours and symptoms that last 12 to 24 hours (Moravek et al., 2004) While, the emetic syndrome is characterized by an acute attack of nausea and vomiting within 1-5 hours after a meal. The illness is relatively mild and recovery within 12-24 hours (Ehling-Schultz et al., 2005; Kawamura et al., 2005 and Taylor et al., 2005).

Pseudomonal infections can affect the entire alimentary canal, causing necrotizing enterocolitis showing irritability, signs of dehydration, vomiting, watery diarrhoea with foul smell, dehydration, abdominal distension and signs of peritonitis. Pseudomonas aeruginosa has been implicated in epidemics of moderate to severe diarrhoea in children, in a form of enteric fever referred to as Shanghai fever, a syndrome associated with diarrhoea or constipation, rash and fever persisting as long as 1-2 weeks. Moreover, it has been incriminated in cholera-like illness (Todar, 2002). 


\section{(d) Effect of activation of lactoperoxidase system on shelf-life of raw milk:}

The dairy industry has been faced with the control of psychrotrophs for many years. Though preservation of psychrotrophs from entering milk is the best method and one that is technically feasible, it is difficult to achieve. Human errors that result in improperly cleaned, sanitized and handled equipment allow psychrotrophs to enter raw and pasteurized milk. Hence, control must focus on destruction of psychrotrophs or prevention of their growth in milk.

Preservation of milk is one of the problems in dairy industry. This problem could be solved from one side by using safe, cheap and effective chemical preservatives. Activation of lactoperoxidase system could be applied before cold storage of milk to improve its quality and extend the shelf-life of raw milk in tropical countries where refrigeration of milk immediately after milking is not feasible (Muir, 1996 and Graells et al., 2003).

The results recorded in Figure (1) pointed out that the psychrotrophic bacterial count in raw milk which activated by addition of Sodium thiocyanate $(\mathrm{NaSCN})$ and Hydrogen peroxide $\left(\mathrm{H}_{2} \mathrm{O}_{2}\right)$ at concentration of $10: 15,14: 30$ and $30: 100 \mathrm{ppm}$, respectively and kept at room temperature. The sign of spoilage of untreated milk was obvious after 8 hours when the psychrotrophic bacterial count $(\log )$ reached 6.59 from the initial count 4.54 while activation of lactoperoxidase system by 10 : 15 and $14: 30 \mathrm{NaSCN}: \mathrm{H}_{2} \mathrm{O}_{2}$ will delay spoilage of raw milk to 16 hours and the count reached 6.88 and 6.7, respectively. The shelf life of raw milk activated with $30: 100 \mathrm{ppm}$ will prolong to 24 hours of storage. The $\mathrm{pH}$ value decreased from 6.63 to 4.20 within 8 hours in the untreated milk while decreased to 4.20 and 4.50 within 16 hours in treated milk samples with $\mathrm{NaSCN}: \mathrm{H}_{2} \mathrm{O}_{2} 10: 25$ ppm, respectively. (Figure 2)

On the other hand, the sign of spoilage in treated milk with NaSCN : $\mathrm{H}_{2} \mathrm{O}_{2}$ at $10: 20,14: 30$ and $30: 100 \mathrm{ppm}$ and kept at refrigerator was observed after 20,20 and 30 hours of storage as the psychrotrophic bacterial count increased to reach 5.79, 5.52 and 6.41, respectively (Figure 3). However, overnight or one day storage may be possible. The spoilage may be due to the decrease in $\mathrm{pH}$ value. The $\mathrm{pH}$ values decreased to reach 4.5 after 12 hours in untreated milk and 4.3 and 4.5 in milk activated by $10: 20,14: 30$ after 20 hours of storage for both concentrations. While, in samples activated by $30: 100$ the $\mathrm{pH}$ value decreased to reach 4.1 by the end of $30^{\text {th }}$ hour of storage. The 
increased acidity in untreated milk may be due to the activity of lactic acid bacteria normally present in milk but in treated milk may be due to the oxidation products of thiocyanate (Pruitt and Tanovuo, 1982) as LP system suppresses acid development by combating lactic acid bacteria (Muir, 1996). The action of LP system may be explained on the basis of production of bacterial inhibitor hypothiocyanate (OSCN) which interferes with metabolism of bacteria with regard to oxygen uptake and lactic acid metabolism thereby inhibiting growth (Dewit and Van Hooydonk, 1996). The antibacterial effect of the LP-system is mediated by short-lived oxidation products of thiocyanate by hydrogen peroxide and has been identified as $\mathrm{OSCN}^{-}$and $\mathrm{O}_{2} \mathrm{SCN}^{-}$. These oxidation products react rather specifically with free $\mathrm{SH}$-groups in proteins, thereby oxidizing them to the corresponding sulfonyl derivatives, which in turn undergo hydrolysis to yield sulfonic acids. Functional SH-groups are destroyed in this way by the LP-system, thereby causing an interference with the metabolism of the bacteria. In some bacteria, such as streptococci and lactobacilli, this results in a temporary inhabitation, after which bacteria recover. In other bacteria, such as most strains of E. coli, Salmonella and Pseudomonads spp., it leads to an irreversible inhibition; i.e., the killing of the bacteria (IDF, 1988).

Bjorck (1978) concluded that the treatment had no effect on the physicochemical properties of milk and did not lead to the accumulation of resistant bacteria. From the public health point of view, Gothefors and Marklund (1975) stated that the LP system degrades various carcinogens and protects the human cells from the toxicity of hydrogen peroxide. Also, it is easier to apply than the traditional one in which hydrogen peroxide alone in concentration up to $800 \mathrm{ppm}$ is used (Tentoni et al., 1968). The obtained results were in parallel manner with (Ghosh and Ghatak, 1995; Al-Hawary 1999 and Girgis et al., 1999). While, the recorded result were in accordance with Patel and Sannabhadti (1993) who found that, combination between LP-treatment and heat treatment did not give marked enhancement in shelf-life of raw milk as compared to LP-treatment alone. Also, LP after heat treatment gave slightly better inhibitory influence as compared to heat treating after LP.

Strict hygienic measures should be highly recommended during production of raw milk, processing; transportation and storage of pasteurized milk to ensure a high quality product and to safeguard consumers from public health hazards. The use of lactoperoxidase system to prolong the shelf life of raw milk is recommended in absence of method of cooling during transportation. 


\section{REFERENCES}

Al-Hawary (1999): The effect of lactoperoxidase system on Bacillus cereus and milk quality. Alex. J. Vet. Sci., 15(5): 967-973.

Arques, J.L.; Rodriguez, E.; Nunez, M. and Medina, M. (2008): Antimicrobial activity of nisin, reuterin and the lactoperoxidase system on listeria monocytogenes and staphylococcus aureus in cuajada, a semisolid dairy product manufactured in Spain. J. Dairy Sci., 91(1): 70-75.

APHA (1992): American Public Health Association. Compendium of Methods for the Microbiological Examination of Foods. $3^{\text {rd }}$ Ed., Washington, DC, 20005.

Bailey, W.R. and Scott, E.G. (1998): Diagnostic Microbiology. A Textbook for the Isolation and Identification of Pathogenic Microorganisms. The C.V. Mosby Company Saint Louis.

Bjorck, L. (1978): Antibacterial effect of the lactoperoxidase system on psychrotrophic bacteria in milk. J. Dairy Res., 45: 109-118.

Bodyfelt, F. (1980): Heat resistant psychrotrophs affect quality of fluid milk. Dairy Record, 81(3): 96-98.

Bramley, A.J. and Mckinnon, C.H. (1990): The microbiology of raw milk. Dairy Microbiology, The Microbiology of Milk. $2^{\text {nd }}$ Ed. Robinson, R.K. Elsevier Applied Science.

Cogan, T.M. (1977): Heat resistant lipases and proteinases and the quality of dairy products. Ann. Bull. Int. Dairy Fed. Document, 118: 26-32.

Cousin, M.A. (1982): Presence and activity of psychrotrophic microorganisms in milk and dairy products. A review. J. Food Prot., 45: 172-207.

Dewit, J.N. and Van Hooydonk, A.C.M. (1996): Structure, function and application of lactoperoxidase in natural antimicrobial system. Neth. Milk Dairy J., 50: 227.

Ehling-Schultz, M.; Svensson, B.; Guinebretiere, M.H.; Lindback, T.; Andersson, M.; Schulz, A.; Fricker, M.; Christiansson, A.; Granum, P.E.; Martbauer, E.; Nguyen, C.; Salkinooji-Salonen, M. and Scherer, S. (2005): Emetic toxin formation of Bacillus cereus is restricted to a single evolutionary lineage of closely related strains. Microbiol., 151(1): 183-197.

El-Shenawy, M.A.; Garcia, H.S. and Marth, E.H. (1990): Inhibition and inactivation of Listeria monocytogenes by the lactoperoxidase system in raw milk, buffer or semi-synthetic medium. Milchwissenschaft, 45(10): 638-640. 
Fweja, L.W.; Lewis, M.J. and Grandison, A.S. (2007): Alternative strategies for activation of the natural lactoperoxidase system in cow's milk: trails in Tanzania. J. Dairy Res. 74(4): 381-386.

Ghosh, A. and Ghatak, P.K. (1995): Influence of lactoperoxidase system on lipolysis of raw milk. Indian J. Dairy Sci., 47: 712.

Girgis, Elein, S.; Abd El-Ghany, I.H.I.; Yousef, Laila, M. and Mohammed, Laila, M. (1999): Effect of milk pretreatment and storage conditions on the properties and keeping quality of Ras cheese. Dairy Department, Fac. Agric. Cairo Univ., Egypt. Egyptian J. Dairy Sci. 27: 153-166.

Gothefors, L. and Marklund, S. (1975): Lactoperoxidase activity in human milk and in saliva of newborn infants. Infect. Immun., 11: $1210-1215$.

Graells, C.G.; Opstal, I.V. and Michiels, C.W. (2003): The lactoperoxidase system increases efficacy of high-pressure inactivation of foodborne bacteria. Int. J. Food Microbiol., 81(3): 211-221.

IDF, International Dairy Federation (1985): Estimation of number of psychrotrophic microorganisms-rapid counting technique $25 \mathrm{hr}$ at $21{ }^{\circ} \mathrm{C}$. IDF 132.

IDF, International Dairy Federation (1988): Temporary preservation of raw milk by activation of LP-system. Bull. IDF No. 234, 9-15.

Jay, J.M. (1997): Modern Food Microbiology. Chapman \& Hall, New York.

Kawamura, S.K.; Hirama, Y.; Agata, N.; Ito, H.; Torii, K.; Takeno, A.; Hasegawa, T.; Shimomura, Y. and Ohta, M. (2005): Quantitative analysis of cereulide, an emetic toxin of Bacillus cereus, by using rat liver mitochondria. Microbiol. Immunol., 49(1): 25-30.

Kirin, S. (2001): The effect of cooling procedure on the characteristics and quality of raw milk. Miljekarstvo, 51(2): 151-159.

Lampert, L.M. (1975): Modern Dairy Products. $3^{\text {th }}$ Ed., Chemical Publ. Co., Inc., New York.

Law, B.A. (1979): Reviews of the progress of dairy science: Enzymes of psychrotrophic bacteria and their effects on milk and milk products. J. Dairy Res., 46: 573-588.

McClements, J.M.; Patterson, M.F. and Linton, M. (2001): The effect of growth stage and growth temperature on high hydrostatic pressure inactivation of some psychrotrophic bacteria in milk. J. Food Prot., 64(4): 514-522. 
Meer, R.R.; Baker, J.; Bodyfelt, F.W. and Griffiths, M.W. (1991): Psychrotrophic Bacillus spp. in fluid milk products: A review. J. Food Prot., 54: 969-979.

Metwally, M. and Nasr, M. (1992): Preservation of raw milk by activation of the lactoperoxidase system. Egypt. J. Food Sci., 20: 175.

Moravek, M.; Wegscheider, M.; Schulz, A.; Dietrich, R.; Burk, C. and Martlbauer, E. (2004): Colony immunoblot assay for the detection of haemolysin BL enterotoxin producing Bacillus cereus. FEMS Microbiol. Lett., 238(1): 107-113.

Muir, D.D. (1996): The shelf-life of dairy products. I. Factors influencing raw milk and fresh products. Int. J. Dairy Technol., 49(1): 24-32.

Patel, D. and Sannabhadti, S. (1993): Effect of activation of lactoperoxidase system on bacteriological quality of buffalo raw milk. Indian J. Dairy Sci., 46: 483.

Prieto, B.; Franco, I. and Bernardo, A. (2002): Proteolytic and lipolytic changes during the ripening of Leon raw cow's milk cheese, a Spanish traditional variety. Int. J. Food Sci. Technol., 37: 661-671.

Pruitt, K.M. and Tanovuo, J. (1982): Kinetics of hypothiocyanite production during peroxidase catalyzed oxidation of thiocyanate. Biochem. Biophys. Acta, 704: 204-214.

Taylor, J.M.; Sutherland, A.D.; Aidoo, K.E. and Logan, N.A. (2005): Heat-stable toxin production by strains of Bacillus cereus, bacillus firmus, Bacillus megaterium, Bacillus simplex and bacillus licheniformis. FEMS Microbiol. Lett., 242(2): 313-317.

Tentoni, R.; Pastore, M. and Ottogalli, G. (1968): Hydrogen peroxide for milk collection under difficult conditions. Ann. Microbiol., 18: 85-123.

Teo, Y.L.A.; Ziegler, G.R. and Knable, S.J. (2001): Optimizing detection of heat injured Listeria monocytogenes in pasteurized milk. J. Food Prot., 64(7): 1011.

Todar, K. (2002): Pseudomonas aeruginosa. In: Todar's Online Textbook of Bacteriology.

Zajac, M.; Gladys, J.; Sharzynska, M.; Harnuly, G. and Bjorck, L. (1983): Changes in bacterial quality of raw milk activated by activation of its lactoperoxidase system and stored at different temperatures. J. Food Prot., 46(12): 1065. 